\title{
Design of parabolic solar dish tracking system using arduino
}

\author{
Asif Ahmed Rahimoon ${ }^{1}$, Mohd Noor Abdullah², Dur Muhammad Soomro ${ }^{3}$, Murad Yahya Nassar ${ }^{4}$, \\ Z.A. Memon ${ }^{5}$, P.H. Shaikh ${ }^{6}$ \\ ${ }^{1,2,3,4}$ Green and Sustainable Energy (GSEnergy) Focus Group, Faculty of Electrical and Electronic Engineering, \\ Universiti Tun Hussein Onn Malaysia, Malaysia \\ ${ }^{5,6}$ Department of Electrical Engineering, Mehran University Jamshoro, Pakistan
}

\begin{tabular}{l}
\hline Article Info \\
\hline Article history: \\
Received Jun 10, 2019 \\
Revised Aug 12, 2019 \\
Accepted Aug 26, 2019 \\
\hline
\end{tabular}

\section{Keywords:}

Concentrating solar power (CSP)

Direct normal irradiance (DNI)

Dual axis tracking technologies

Photovoltaic solar panel

\begin{abstract}
This paper demonstrates the designing parameters of a solar parabolic dish prototype for rustic areas with great solar irradiance rate availability, where have no access of electricity services or low-income people survives to buy a stove (electric or gas). The solar parabolic dish prototype intends a solution against these types of remedies and pursues solar light to work. The parabolic dish has a polished surface, where the solar radiations fall and collected at a single concentrated focal point. At this point the collected form of energy is used to derive different thermal applications like as; cooking $\&$ heating with single and dual axis schemes. This paper discusses the important stages of dual axis prototype; implementation, solar location strategy, the analysis in terms of theory, structural design \& material. The dual axis prototype is implemented through the help of Arduino chipboard that is easily in maintenance, along with that this prototype is configured with anti-lock Hbridge (L298) module to overcome the control circuit complexity and AVR modules. Two rotational motors of $12 \mathrm{~V}$ are installed on $4 * 4 \mathrm{ft}$ designed aluminum frame with a dual-axis tracking system. The jerks among trackers are also reduced with this prototype which maintains the experimental declination angle about $22.47^{\circ}$.To finish, this paper results that parabolic solar dish tracker obtains $3.43 \%$ improved power efficiency in comparison of photovoltaic panel tracker.
\end{abstract}

Copyright $(2020$ Institute of Advanced Engineering and Science. All rights reserved.

\section{Corresponding Author:}

Mohd Noor Abdullah,

Green and Sustainable Energy (GSEnergy) Focus Group,

Faculty of Electrical and Electronic Engineering,

Universiti Tun Hussein Onn Malaysia,

Parit Raja, 86000 Batu Pahat, Johor, Malaysia.

Email: mnoor@uthm.edu.my

\section{INTRODUCTION}

Energy production is the main issue of all developed countries to achieve their esteem goal with the development of energy extraction tools. Renewable energy especially solar energy resources are getting momentum as an alternate source of energy production due to their high availability around the world. Although, research track is still continues to pluck out the electricity from solar irradiances with two Systems; solar photovoltaic and concentrated solar power technologies [1-2]. The solar panels are widely used to meet the required electricity demand on a major and minor level with different controlling schemes but could not meet the timeline due to its low efficiency, drawbacks and common problems. Thus, a lot of investigation was performed and still continues to pump up the efficiency of solar panels in terms of maximization of panel output power, the increment in solar cell efficiency and use of solar tracking technology [3-5]. From these suggestions, the tracking technology is proven to be efficient for solar panel Systems but could not increase the solar panel output power due to connected issues like as the misalignment in positioning, dust and dusk issues. The tracking system involves two types of drives i.e. an active and 
passive type trackings with multiple modes. The modes of these drives are single axis and dual axis including temperature, solar irradiation and installed system area factors. The active drive type tracking system is much adopted drive compared to passive drive with single axis, vertical single axis and azimuth dual axis tracking Modes [6-8]. Europe, US, India and China are using tracking system to enhance the efficiency of solar thermal power technology. Similarly, the parabolic solar dish Systems are also implemented for the indirect generation of heat and power. In this technology the extraction of electricity using solar system also addressed with tracking scheme and faces the same tracking alignment and uncontrolled temperature issue that makes the system low- efficient. Therefore, the energy production increases with tracking compared to non-tracking solar systems [9-12].

The focus of this research is to design an optimum output based parabolic solar dish tracker to enhance the PV cell efficiency and eliminating tracking challenges. Therefore, this research is based on solar tracking scheme using Arduino controller with dual axis tracking mode. The proposed parabolic PV system is constructed with dual axis mechanism that is controlled with electronic circuitry which includes light dependent resistor (LDR) sensing module, $12 \mathrm{~V}$ irreversible power motor, $12 \mathrm{~V} \mathrm{DC}$-gear motor, and HBridge drive module as shown in Figure 1.

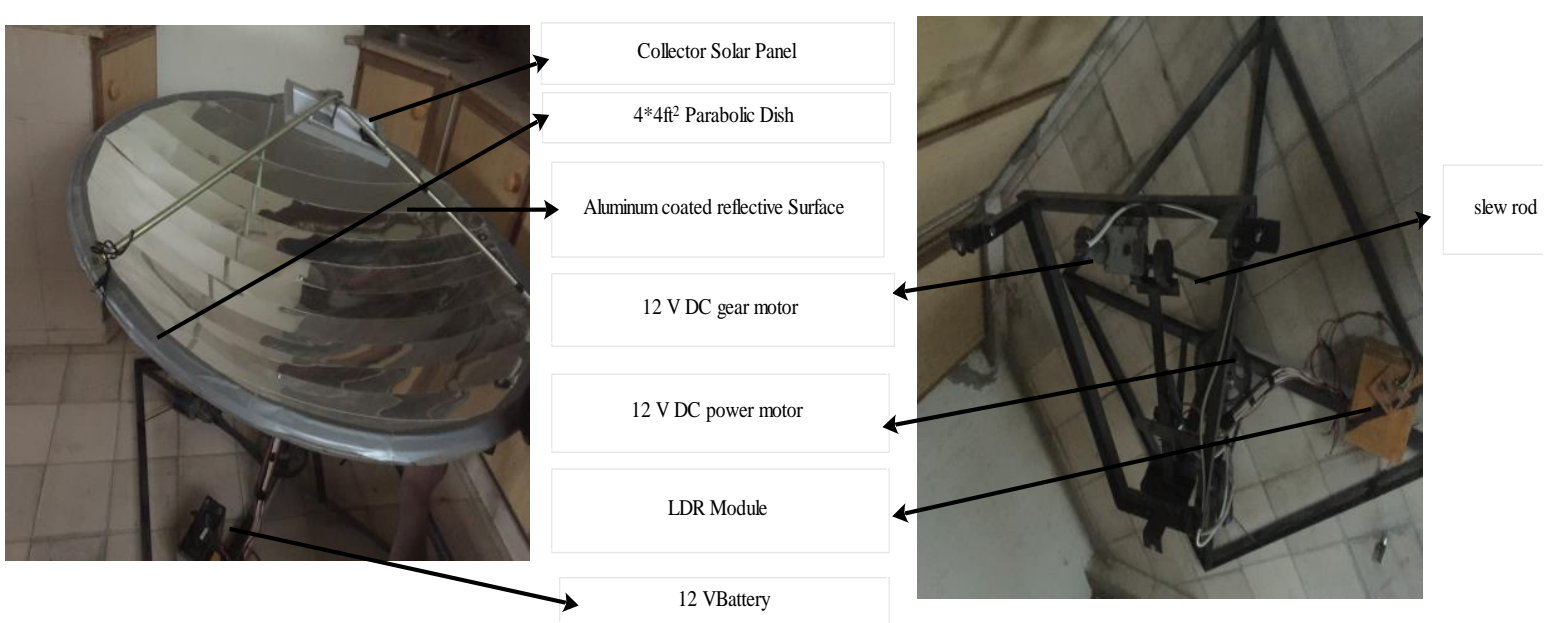

Figure 1. Designed system parameters of parabolic dish PV system

\section{SOLAR PANEL}

The $10 \mathrm{~W}$ poly-crystalline solar panel is tested with two setups. The first setup includes the analysis of standalone PV panel tracking while in the second setup $10 \mathrm{~W}$ PV panel was placed perpendicular to the aluminum coated reflective surface on designed Parabolic-Dish. The rays accumulating at focus point of the polished surface reflects toward the installed solar panel to convert it into electricity in closed loop feedback strategy mode.

\section{CONCENTRATED SOLAR POWER}

Concentrated solar power (CSP) technology is one of the way to generate electricity by producing heat when sunlight focuses on a receiver [6, 12-13]. This technology uses optical component either mirrors or lenses or any reflective type material to concentrate a large area of sunlight into a small beam to heat up the receiver for steam converted to electricity [7-9]. There are three common methods to concentrate the sunlight, i.e. solar dish, solar trough and a linear fresnel as illustrated in Table 1. Parabolic dish is mainly used with reflective mirrors along with fuel based Stirling engines for thermal to electric conversion [17-19]. While the parabolic trough is used in a variety of applications including industrial steam production for electricity, process heat application, large scale heating and cooking [20-22]. The linear fresnel reflectors are made up of thin mirror strips to focus daylight onto tubes through which working liquid is pumped for fixed point energy generation applications $[6,23]$. 
Table 1. Types of CSP Technology [22]

\begin{tabular}{llll}
\hline & \multicolumn{1}{c}{ Parabolic-Dish } & \multicolumn{1}{c}{ Parabolic Trough } & Linear Fresnel \\
\hline Uses & $\begin{array}{l}\text { In a single application or grouped } \\
\text { in solar dish farms }\end{array}$ & $\begin{array}{l}\text { For large grid-connected power projects in } \\
\text { the 30-200Mw size }\end{array}$ & Single applications \\
Cost (USD/W) & $1.3-12.6$ & $2.7-4.0$ & N/A \\
Tracking Axis & Single and Dual & Single or dual & Single and Dual \\
Concentration Type & Focal point & Focal line & Focal line \\
Receiver & Mobile & Mobile & Fixed \\
Advantage & High Conversion Efficiency & Concentrating sunlight to a small focus & provides additional \\
& Smaller PV area is needed & line & design flexibility \\
Disadvantage & The transform of energy needs & The Freezing Point is too high & Shading affect is more \\
& the strong tracking system & & than parabolic trough \\
\hline
\end{tabular}

\section{LOCATION AND CLIMATE}

Pakistan lies in Indus Tsangpo suture zone (ITSZ) with four seasons like spring, summer and autumn and winter. The research work was performed in largest city of Pakistan i.e. Karachi located on coordinates of $24.8607^{\circ} \mathrm{N} \& 67.0011^{\circ} \mathrm{E}$, containing average high humidity $60.74 \%$ and less rainfall rates averagely $(25 \mathrm{~mm})$ [30]. The annual recorded average range of low temperature for Karachi is about $20.33^{\circ}$ and high temperature is about $41.56^{\circ}$. Seasons in Pakistan as shown in Table 2.

Table 2. Seasons in Pakistan [30]

\begin{tabular}{cc}
\hline Seasons & Time period \\
\hline Spring & March to May \\
Summer & June to September \\
Autumn & October to November \\
Winter & December to February \\
\hline
\end{tabular}

\section{HARDWARE DEVELOPMENT OF PROPOSED SYSTEM}

The parabolic concentrator is generally a structured with concave type reflective material to capture solar irradiance with attached receiver at focal point. The temperature received at reflective surface is dependent of fabricated surface as (mirror, aluminum sheet, stainless steel and flux sheet) to attain maximum level of solar energy. This research is designed with twelve cross-sectional aluminum coated reflective sheets to reflect direct normal irradiances (DNI). The overview of methodology represents the complete status of investigated components that are suitably operated in this proposed parabolic solar dish PV tracking system. The numerical modeling of parabolic dish is attained by using parabola calculator 2.0 with listed parameters in Table 3. The block diagram of the proposed parabolic dish design is as shown in Figure 2.

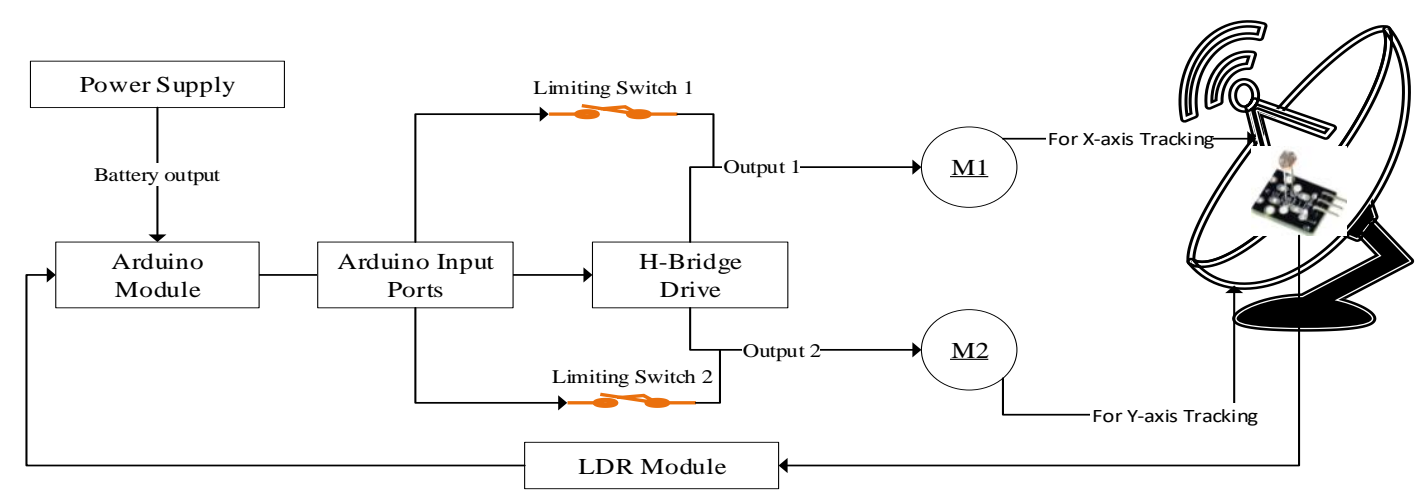

Figure 2. Block diagram of proposed parabolic dish PV system

\subsection{Light Dependent Resisters (LDR) Module}

Photo resistors as LDRs are used to trap the position of a parabolic dish. The sensitivity of these resistors changes according to exposure of sun light. Four (4) LDRs (2 each for $\mathrm{x}$ and $\mathrm{y}$-axes) were mounted in wall shape at the top of prototype frame to avoid from shadow that creates the cosine effect. 
Table 3. Parameters of Designed Parabolic Dish

\begin{tabular}{cccc}
\hline S\# & Parameters & Values & Units \\
\hline 1 & Linear Diameter & 04.58 & $\mathrm{Ft}$ \\
2 & Diameter & 04.00 & $\mathrm{Ft}^{2}$ \\
3 & Depth & 01.00 & $\mathrm{Ft}$ \\
4 & Focal Length & 01.00 & $\mathrm{Ft}$ \\
5 & Volume & 06.26 & $\mathrm{Ft}^{3}$ \\
6 & Focal Length/Diameter & 00.25 & $\mathrm{Ft}$ \\
\hline
\end{tabular}

\subsection{Arduino UNO Controller}

Arduino Uno is a microcontroller board of series Atmega328 chip [9-11]. It was used to control the complete circuitry with fixed architecture mode. This mode allows the DC motors to operate with their pre-programmed tracking assembly along with installed limiting switches and H-Bridge drive circuit.

\subsection{H-Bridge Drive}

This Drive is generally used to control and optimize the speed of tracking motors with internally generated (PWM) pulses [12-14]. This designed parabolic PV system uses L298 H-Bridge drive which has built in $5 \mathrm{~V}$ AVR to operate the system in isolated mode along with elimination of external circuit complexity as required by simple solar panel tracking scheme.

\subsection{Motors}

The selection of motors is based on the assembly control, mainly used for different types of rotational applications. Generally, $12 \mathrm{~V}$ motors are commonly assembled with tracker strategy but they get mis-alignment issue due to un-optimized control setup [24-25]. Therefore, the proposed dual axes tracking system was installed with $12 \mathrm{~V} \mathrm{DC}$ gear motor with slew rod technique for altitude angle control and $12 \mathrm{~V}$ power motor for azimuth angle.

The tracking angles are generally divided into two types i.e. altitude (E-W) and azimuth (N-S) angles to balance the maximum rate of DNI in single or dual axes tracking drive modes. The flow chart of altitude and azimuth angle is shown in Figure 5 a \& 5 b respectively.

Altitude angle is a trajectory path that is observed from the vertical surface of an observer. It is oriented with Y-axis and also known as tilt angle [28-29].In this designed system, altitude angle in clockwise and clockwise direction with $12 \mathrm{~V}$ DC gear motor assembly was obtained by using (1).

$$
\begin{aligned}
& \sin \alpha_{s}=\sin \delta \sin \varphi+\cos \delta \cos \omega \cos \varphi \\
& \delta=23.45^{\circ} \times \cos \left\{\frac{360}{365} \times(\mathrm{d}+10)\right\}
\end{aligned}
$$

Where, $\alpha_{\mathrm{s}}$ represents the altitude angle, $\delta$ indicates the sun declination angle, $\varphi$ represents latitude angle, $\omega$ denotes the hour angle and $d$ is used for day of the year.

Azimuth angle (A) is like a compass direction with north equals to $0^{\circ}$ and south as $180^{\circ}$. It is used to measure spherical coordinate of the system [29]. This angle was formulated in clockwise and clockwise direction for $12 \mathrm{~V}$ DC power motor assembly by using (3).

$$
\mathrm{A}=\cos ^{-1}\left(\frac{\sin \delta \cos \varphi-\cos \delta \cos \omega \sin \varphi}{\cos \alpha}\right)
$$

Where, $\alpha$ represents the elevation angle.

The flowchart for tracking angles is programmed in Arduino controller with suitable instruction set to track the system in optimal mode. This mode of instruction is dependent of LDR signals that are transmitted to track and detect system positioning with less motor issues. The starting of motor is configured when the voltage difference in LDR module is transferred to Arduino controller. The complete trajectory with Arduino controller is monitored through closed loop scheme along with limiting switches. Layout of dual axis tracking as shown in Figure 3. Overview of solar geometry as shown in Figure 4. 


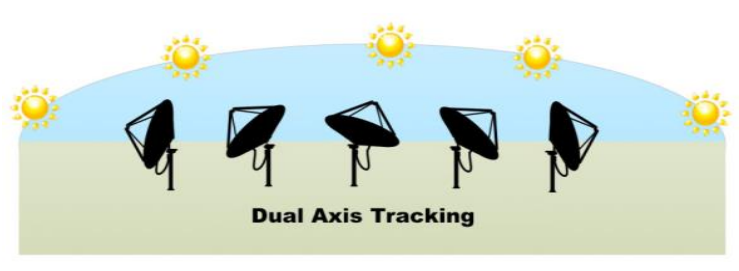

Figure 3. Layout of dual axis tracking

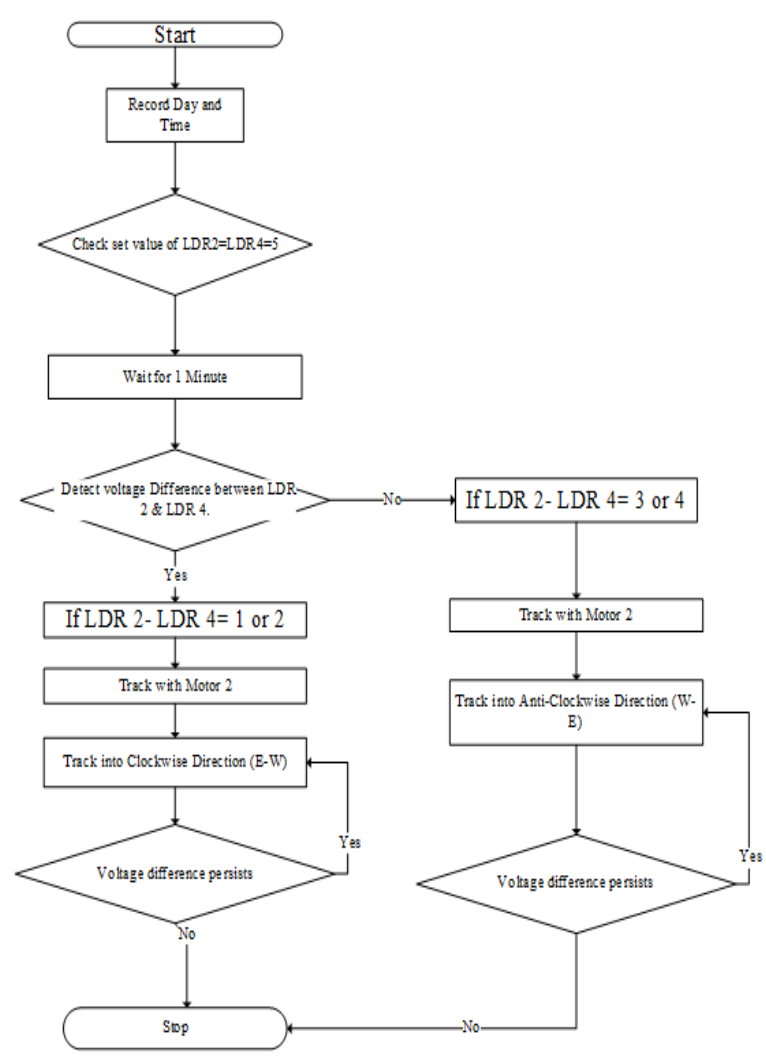

(a)

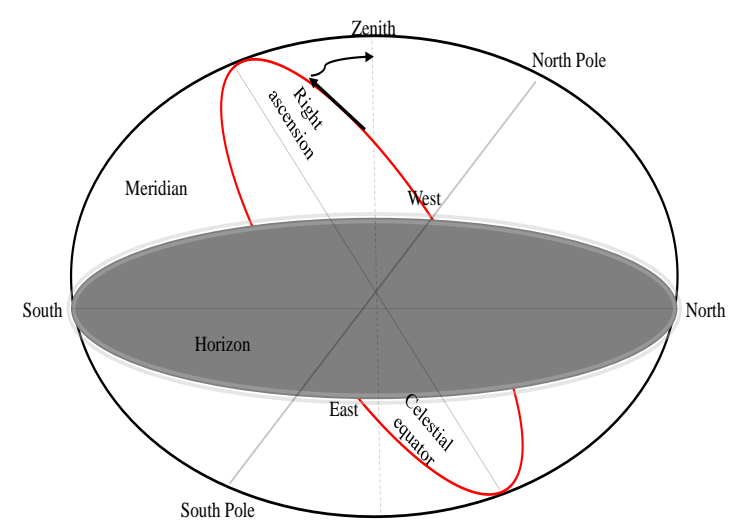

Figure 4. Overview of solar geometry

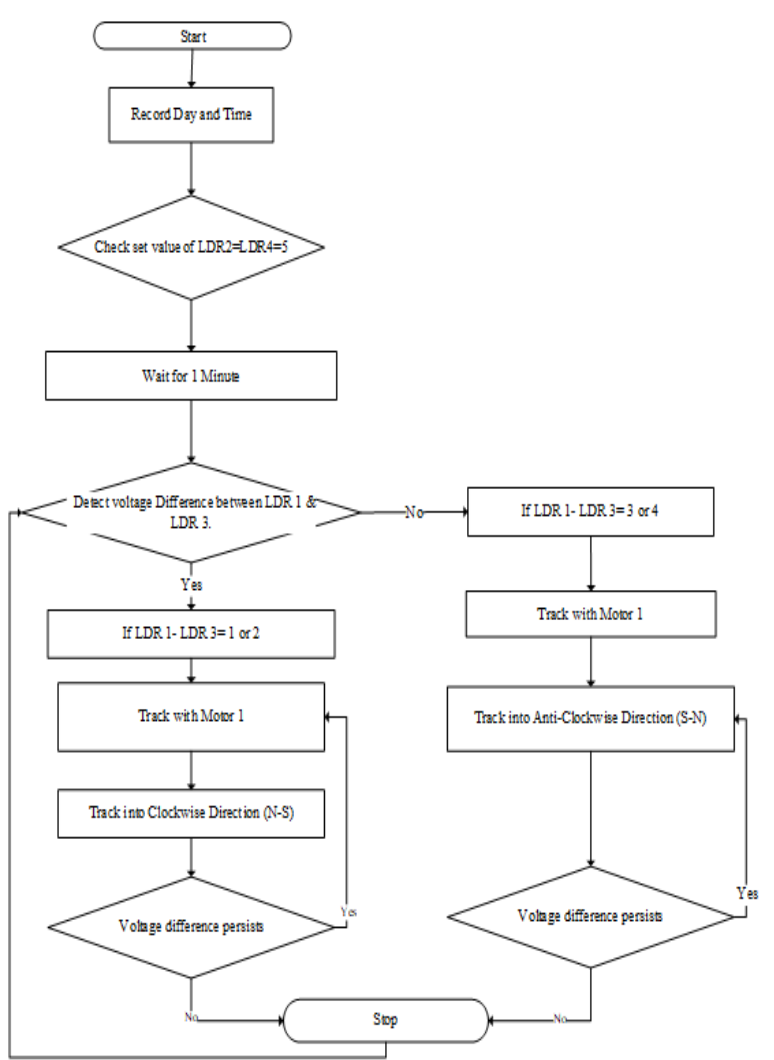

(b)

Figure 5. Flow chart of dual axis tracking mode for the proposed parabolic dish PV system, (a). Tracking algorithm for altitude angle, (b). Tracking algorithm for azimuth angle

\section{RESULT AND DISCUSSION}

This paper presents the tracking scheme layout of parabolic dish PV system for enhancement of PV system to extract electricity with indirect conversion method. The testing and analyzing of proposed parabolic dish tracker compared to $10 \mathrm{~W}$ solar PV system was performed on $27^{\text {th }}$ November 2018 at 9 am $4 \mathrm{pm}$. The comparative result with generated output power variable is as depicted in Table 4 and Figure 6. The tracking angles of both axis starts with detected signal. As in the Table 4; the starting tilt angle about $23.73^{\circ}$ while, azimuth angle was $131.10^{\circ}$. In general, solar operated projects show their maximum output at full shine hours so, in this comparative analysis the solar PV panel gives rated power as $6.17 \mathrm{~W}, 8.81 \mathrm{~W} \& 9$ W from $12 \mathrm{pm}-2 \mathrm{pm}$. Similarly, the result obtained from proposed parabolic dish PV tracking system on same 
tabulated time period and angles was $10.08 \mathrm{~W}, 11.78 \mathrm{~W} \& 13.8 \mathrm{~W}$. The optimized output level of proposed parabolic solar dish tracking system is proven to be efficient by comparing PV panel. The system attains it's tracking levels according to programmed solar geometrical parameters. This system also improves the installed motor assembly tracking errors along with some system limitations due to right motor selection.

Table 4. Result of Designed Parabolic Dish based PV System

\begin{tabular}{|c|c|c|c|c|c|}
\hline \multicolumn{2}{|c|}{ Tracking Angles } & \multirow[t]{2}{*}{ Time } & \multirow{2}{*}{$\begin{array}{c}\text { Solar PV Tracking panel } \\
\text { Output Power }(\mathrm{W})\end{array}$} & \multirow{2}{*}{$\begin{array}{c}\text { Designed Parabolic PV Tracking system } \\
\text { Output Power (W) }\end{array}$} & \multirow{2}{*}{$\begin{array}{l}\% \text { of Improved } \\
\text { Power } \\
\end{array}$} \\
\hline Altitude & Azimuth & & & & \\
\hline $23.73^{0}$ & $130.10^{0}$ & 9am & 2.57 & 5.54 & $2.97 \%$ \\
\hline $33.15^{0}$ & $141.80^{\circ}$ & $10 \mathrm{am}$ & 3.37 & 6.73 & $3.36 \%$ \\
\hline $40.07^{0}$ & $157.02^{0}$ & $11 \mathrm{am}$ & 3.72 & 7.48 & $3.76 \%$ \\
\hline $43.34^{0}$ & $175.27^{0}$ & $12 \mathrm{pm}$ & 6.17 & 10.08 & $3.91 \%$ \\
\hline $42.19^{0}$ & $177^{0}$ & $1 \mathrm{pm}$ & 8.81 & 11.78 & $2.97 \%$ \\
\hline $36.92^{0}$ & $178.2^{0}$ & $2 \mathrm{pm}$ & 9 & 13.8 & $4.8 \%$ \\
\hline $28.58^{0}$ & $179.8^{0}$ & $3 \mathrm{pm}$ & 6.65 & 10 & $3.05 \%$ \\
\hline $18.26^{0}$ & $179.8^{0}$ & $4 \mathrm{pm}$ & 5.97 & 8.6 & $2.63 \%$ \\
\hline
\end{tabular}

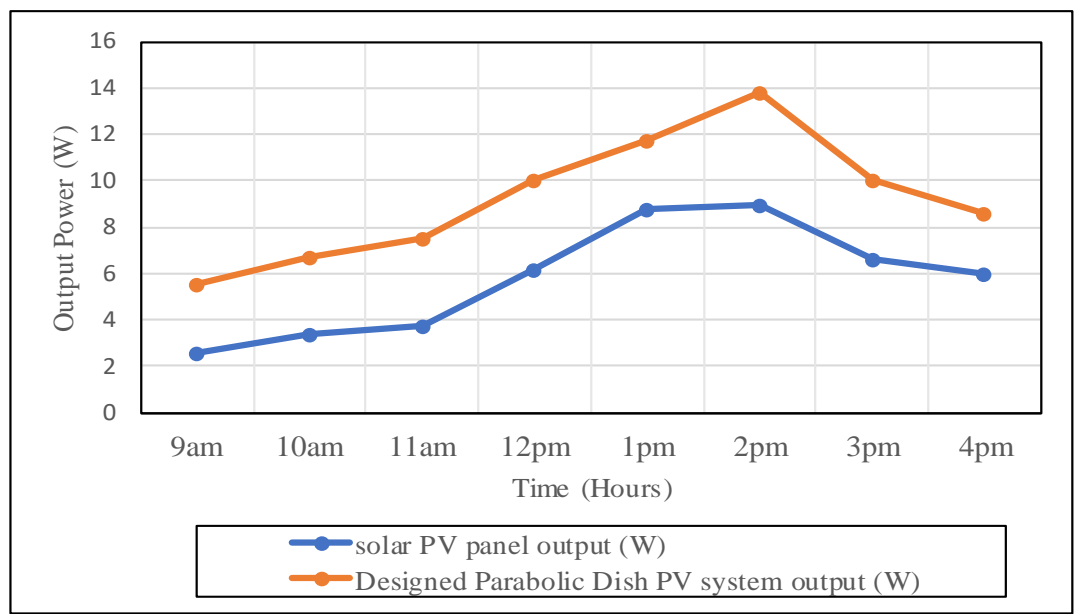

Figure 6. Comparative output power of PV panel vs proposed parabolic PV system

\section{CONCLUSION}

This research involves the designing of CSP system with PV module to capture maximum solar irradiation in less brighten areas. Aluminum polished surface parabolic dish with twelve cross sectional view was developed with integration of PV panel to enhance the system output power. The dual axis closed loop tracking mechanism was installed with $4 * 4 \mathrm{ft}^{2}$ parabolic dish, LDR sensor module, $12 \mathrm{~V}$ DC power motors, $\mathrm{H}$-Bridge drive \& Arduino Controller. The $10 \mathrm{~W}$ polycrytalline solar panel was used as payload reciever for parabolic dish to generate optimum level of output power. The outdoor experiment was performed to analyze solar PV tracker and proposed parabolic dish tracker. The results show that the average output power of solar PV panel was about $5.78 \mathrm{~W}$ while, for the proposed parabolic dish PV system was 9.2515 W. Hence, the output power of the designed parabolic dish PV system is $3.43 \%$ more improved than the compared solar PV panel. In future this design can be enhanced by changing controller strategy, by in corporating the overheating protection circuit.

\section{ACKNOWLEDGEMENT}

The Authors would like to thanks to Mehran University of Engineering \& Technology (MUET) Jamshoro, Pakistan and Universiti Tun Hussein Onn Malaysia (UTHM) for supporting this project.

\section{REFERENCES}

[1] Saša Pavlović, Velimir S., Darko V., and Emina P., "Optical Design of a Solar Parabolic Concentrating Collector Based on Trapezoidal Reflective Petals," Journal Energy Power Eng., vol. 9, no. 8, pp. 714-720, 2015.

[2] A. A. Rahioon, P. H. Shaikh, Z. A. Memon, A. Ali, and S. Z. Abbas, "Automatic Positioned Control system for Motorized Parabolic solar Dish,” Journal of Emerging Technologies IBA Sukkur, pp. 3-7, 2018. 
[3] S. Ray and A. K. Tripathi, "Design and development of Tilted Single Axis and Azimuth-Altitude Dual Axis Solar Tracking systems," 1st IEEE Int. Conf. Power Electron. Intell. Control Energy Syst. ICPEICES 2016, pp. 1-6, 2017.

[4] A. Ruelas, N. Velázquez, and L. González, "Design, Implementation and Evaluation of a Solar Tracking System Based on a Video Processing Sensor," Int. J. Adv. Res. Comput. Sci. Softw. Eng., vol. 3, no. 10, pp. 172-178, 2013.

[5] N. M. Arago, T. M. Amado, and J. W. F. Orillo, "Utilization of cassegrain feed parabolic antenna design in increasing the efficiency of photovoltaic module," Int. Conf. Humanoid, Nanotechnology, Inf. Technol. Commun. Control. Environ. Manag. 2014.

[6] L. Jain, T. Jain, Y. Aggarwal, G. Kashyap, J. Anjali, and N. Verma, "Concentrated Solar Power Tracker Using Arduino UNO and Stepper Motor," 3rd Int. Conf. Converg. Technol., pp. 1-6, 2018.

[7] X. Xu, K. Vignarooban, B. Xu, K. Hsu, and A. M. Kannan, "Prospects and problems of concentrating solar power technologies for power generation in the desert regions," Renew. Sustain. Energy Rev., vol. 53, pp. 1106-1131, 2016.

[8] M. Li and J. Dong, "Modeling and simulation of solar Dish-Stirling systems," Asia-Pacific Power Energy Eng. Conf. APPEEC, 2012.

[9] Nitai Pal, at al., "Single Axis Automatic Solar Tracking System Using Microcontroller," TELKOMNIKA (Telecommunication, Computing, Electronics and Control), vol. 12, pp. 8082-8032, 2014.

[10] A. Imran, F. Diyana, M. Rohaizat, and A. Imran, "Dual Axes Solar Tracker," International Journal of Electrical and Computer Engineering (IJECE), vol. 8, no. 3, pp. 1887-1892, 2018.

[11] E. M. H. Arif, J. Hossen, G. R. Murthy, M. Z. H. Jesmeen, and J. E. Raja, "An efficient microcontroller based sun tracker control for solar cell systems," International Journal of Electrical and Computer Engineering (IJECE), vol. 9, no. 4, pp. 2743-2750, 2019.

[12] M. A. Soderstrand, S. B. Lee, and P. Chung, "Mini-dish based hybrid Concentrated Solar Power (CSP) system for home use," Midwest Symp. Circuits Syst., pp. 689-692, 2013.

[13] R. Affandi, C. K. Gan, M. Ruddin, and A. Ghani, "Development of Design Parameters for the Concentrator of Parabolic Dish (PD) Based Concentrating Solar Power (CSP) under Malaysia Environment," J. Appl. Sci. Agric., vol. 9, no. 11, pp. 42-48, 2014.

[14] Y. Kadri and H. Hadj Abdallah, "Performance evaluation of a stand-alone solar dish Stirling system for power generation suitable for off-grid rural electrification," Energy Convers. Manag., vol. 129, pp. 140-156, 2016.

[15] E. A. K and Aldeen, "Experimental steady to produce steam by solar energy using solar dish concentration with copper coil receiver," Int. J. Eng. Innov. Technol., 2015.

[16] A. Z. Hafez, "Simulation, Design and thermal analysis of a solar Stirling engine using MATLAB Article in Energy Conversion and Management March 2014," Energy Convers. Manag., vol. 79, pp. 626-639, 2014.

[17] H. Hijazi, O. Mokhiamar, and O. Elsamni, "Mechanical design of a low cost parabolic solar dish concentrator," Alexandria Eng. J., vol. 55, no. 1, pp. 1-11, 2016.

[18] F. M. Mohamed, A. S. Jassim, Y. H. Mahmood, and M. A. K. Ahmed, "Design and Study of Portable Solar Dish Concentrator," Int. J. Recent Res. Rev., vol. 3, pp. 52-59, 2012.

[19] G. Barreto and P. Canhoto, "Modelling of a Stirling engine with parabolic dish for thermal to electric conversion of solar energy," Energy Convers. Manag., vol. 132, pp. 119-135, 2017.

[20] G. Kumaresan, R. Sridhar, and R. Velraj, "Performance studies of a solar parabolic trough collector with a thermal energy storage system," Energy, vol. 47, no. 1, pp. 395-402, 2012.

[21] M. M. Isa, R. A. Rahman, H. H. Goh, and M. A. Selat, "Optimization Approach for Concentrated Solar Parabolic Trough," Int. J. Appl. Eng. Res., 2014.

[22] M. Mesfin and A. Assefa, "Modeling, Simulation and Performance Evaluation of Parabolic Trough Solar Collector Power Generation System," J. EEA, vol. 27, pp. 81-89, 2010.

[23] Z. Rosnani Affandi, Mohd Ruddin Ab Ghani, Chin Kim Gan, Jano, “A Review of Concentrating Solar Power (CSP) In Malaysian Environment,” Int. J. Eng. Adv. Technol., vol. 3, no. 2, pp. 378-382, 2013.

[24] M. A. J. Paul, "Design and performance analysis of automated two axis solar tracking system for steam generation,” Int. Conf. Energy Effic. Technol. Sustain., pp. 432-437, 2013.

[25] I. A. Sohu, Asif Ahmed, Asadulah Shaikh,S.Abid Ali and Arsaln.A.sohu, "Implementation of Solar Tracking DesignUsing FPGA Tool,” Int. Conf. Comput. Math. Eng. Technol.-(iCoMET), 2019.

[26] M. S. Krishanu Das, Hridi Ghosh, "Single Axis Solar Tracking System using Microcontroller (ATmega328) and Servo Motor," Int. J. Sci. Res. Publ., vol. 6, no. 6, pp. 486-489, 2016.

[27] E. Hossain, R. Muhida, and A. Ali, "Efficiency improvement of solar cell using compound parabolic concentrator and sun tracking system," IEEE Electr. Power Energy Conf.-Energy Innov., pp. 1-8, 2008.

[28] A. Balabel, A. A. Mahfouz, and F. A. Salem, "Design and Performance of Solar Tracking Photo-Voltaic System; Research and Education," Int. J. Control. Autom. Syst., vol. 1, no. 2, pp. 49-55, 2013.

[29] S. Racharla and K. Rajan, "Solar tracking system-a review," Int. J. Sustain. Eng., vol. 10, no. 2, pp. 72-81, 2017.

[30] Anwar iqbal, "Pakistan in the most active quake zone, says usageological survey," Dawn News, Nov 2015. 


\section{BIOGRAPHIES OF AUTHORS}
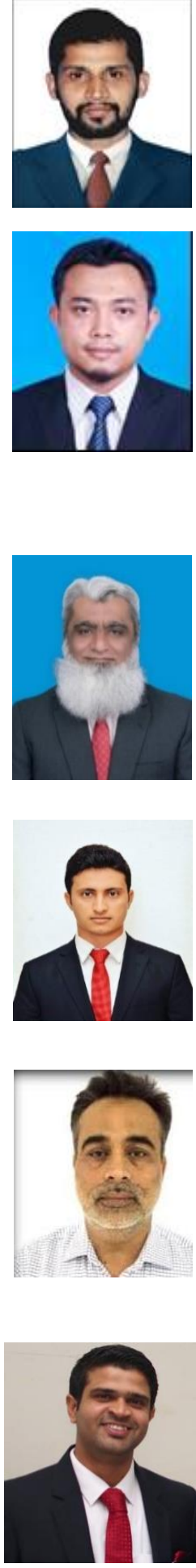

Dr.ZubairA.Memon received his B.Eng. in Electrical Engineering, M. Eng. in Electrical power Engineeringand also PhD degree from Mehran University of Engineering \& Technology (MUET) Jamshoro, Pakistan in 1991, 2005 and 2012 respectively. He has been with MUET Jamshorofrom 1993 to 1998 as a Lecturer in Department of Electrical Power Engineering,(MUET) Jamshoro soon after promoted to Assistant Professor, Associate Professor and Professor respectively in same department from 1998-2013. He is currently serving as Director of postgraduate studies at (MUET) jamshoro. His research interests include power quality, power electronics, electrical machines, linear electrical circuits and modeling \& simulation of power electronic topologies.

Dr. Pervez Hameed Shaikh received his B.Eng. in Electrical Engineering and M. Eng. in Electrical Power Engineering from Mehran University of Engineering \& Technology (MUET) Jamshoro, Pakistan in 2008 and 2011 respectively. He also received a Ph.D degree in Electrical and Electronic Engineering fromUniversity Teknologi Petronas (UTP) in 2015. He has been with (MUET) Jamshoro from 2009 to 2015 as a Lecturer in Department of Electrical Power Engineering and promoted as an Assistant Professor in the same department soon after completing his doctorate in 2015. He is currently serving as Manager in office of Research Innovation and Commercializationat (MUET) Jamshoro. He is also associated with Center for Energy and Development \&Energy and Environmental Engineering Research Group at (MUET) Jamshoro. He was the recipient of the Outstanding Young Engineer Award for 2017 from Pakistan Engineering Council Jamshoro Chapter. His research interests include building energy systems and management, energy economics, conservation and efficiency, renewable energy systems, micro grids, load profiling and forecasting, artificial intelligence (fuzzy systems, neural networks \& adaptive neuro fuzzy inference system, renewable energy, electrical power transmission, distribution \& utilization. 